http://jmscr.igmpublication.org/home/ ISSN (e)-2347-176x ISSN (p) 2455-0450

crossref DOI: https://dx.doi.org/10.18535/jmscr/v8i2.167

Journal Of Medical Science And Clinical Research

\title{
Microvessel Density among the Morphological Types of Multiple Myeloma
}

\author{
Authors \\ Dr Parvathy $\mathbf{V}^{1}$, Dr Sheeja $\mathbf{S}^{2^{*}}$, Dr Renu Thambi ${ }^{3}$, Dr Sankar $\mathbf{S}^{4}$ \\ ${ }^{1}$ Post Graduate Student, Department of Pathology, Govt. Medical College, Kottayam \\ ${ }^{2}$ Associate Professor, Department of Pathology, Govt. Medical College Kottayam \\ ${ }^{3}$ Assistant Professor, Department of Pathology, Govt. Medical College, Kottayam \\ ${ }^{4}$ Professor\& HOD, Department of Pathology, Govt. Medical College, Kottayam \\ *Corresponding Author
}

Sheeja $\mathbf{S}$

Associate Professor, Department of Pathology, Govt. Medical College Kottayam, India

\begin{abstract}
Background: Multiple myeloma is a malignant plasma cell dyscrasia which is characterised by bone marrow plasmacytosis. Multiple myeloma causes $1 \%$ of all cancer deaths in western population.

Objectives

1. To describe the various morphological types of myeloma in bone marrow examination and its kappa and lambda expression

2. To assess the microvessel density using CD 34 in the bone marrow biopsy of patients with multiple myeloma

Methods

Study Design: Descriptive study

Study Population: Study sample includes all the cases of multiple myeloma received in the Department of Pathology during the study period.

Sample Size: 64

Sampling Procedure: Continuous sampling

Results: In our study, myeloma with plasma cell morphology constituted $57.82 \%$ and plasmablastic morphology constituted $42.18 \%$. A high microvessel density above the cut off value was seen in 28 cases $(43.75 \%)$ and a low MVD in 36 cases $(56.25 \%)$.In all the cases monoclonality was proved by kappa and lambda light chain restriction. In the present study, plasmablastic morphology was found to have a higher microvessel density compared to plasmacytic type. It was also suggested that a higher microvessel density was seen in cases with plasma cell percentage of more than $50 \%$ and diffuse plasma cell infiltration in the bone marrow.

Conclusion: Statistically significant association was detected between microvessel density and the plasma cell morphology. Microvessel density was found to be higher with plasma cell morphology.

Keywords: Multiple myeloma; microvessel density (MVD); kappa and lambda.
\end{abstract}

\section{Background}

Multiple myeloma accounts for approximately 10$13 \%$ of all hematological malignancies and $1 \%$ of all malignancies. ${ }^{1}$ Multiple myeloma results from the proliferation of neoplastic B cells that are closely related both morphologically and functionally to plasma cells. 
The clinical manifestations of this disorder result from the proliferation and accumulation of these neoplastic cells and, the effect of marrow replacement by them. The pathologic manifestations are due to over production of certain proteins and constituent polypeptide chains. Bone marrow examination continues to be the cornerstone for establishing a diagnosis in association with other clinical and laboratory parameters $^{[3]}$. Several clinical, laboratory and morphological variables help us in determining the prognosis of the disease. Histological parameters that have a definitive prognostic significance in multiple myeloma are the percentage of myeloma cells in the marrow, pattern of infiltration, plasma cell atypia, and marrow fibrosis ${ }^{[4]}$. Classical cases of myeloma are composed of easily recognizable plasma cells and can be diagnosed without any difficulty. ${ }^{[5]}$ Some cases may pose a considerable diagnostic problem as they exhibit unusual cytological features. This cytological aberration if unrecognized leads to an erroneous diagnosis. ${ }^{[6]}$

Bone marrow examination provides variable information about plasma cell morphology which helps in determining the prognosis of the disease. Cytoplasmic kappa and lambda light chain is useful in distinguishing multiple myeloma from MGUS and reactive plasmacytosis .It provides information regarding the morphology of myeloma and related disorders. So it is a better indicator of myeloma.

Microvessel density, evaluated using CD 34 is a marker for angiogenesis in biopsy meterial and reported to be related to disease activity and poor survival in multiple myeloma patients. Angiogenesis plays an important role in invasion and metastasis of tumours.

\section{Materials and Methods}

Type Of Study: Descriptive study

Period of Study: 18 months (from November, 2017to May, 2018)

Study Setting: Department of Pathology, Govt. Medical College, Kottayam

\section{Study Population}

Study sample include all the cases of the bone marrow aspirate and biopsy of patients of multiple myeloma received in department of Pathology, Govt. medical college Kottayam during the study period.

\section{Sample Size}

Sample size $\frac{Z^{2} S D^{2}}{d^{2}}$

$\mathrm{Z} \alpha=1.96$ at $95 \% \mathrm{CI}$

$\mathrm{SD}=$ standard deviation from the mean value

$\mathrm{D}=20 \%$ of standard deviation

standard deviation of microvessel density in multiple myeloma was found to be 41

So, $\quad \mathrm{SD}=41 \quad \mathrm{D}=20 \%$ of $41=8.2$

Sample size $\frac{Z^{2} S D^{2}}{d^{2}}=\frac{\{1.96\}^{2}\{41\}^{2}}{\{8.2\}^{2}}$

Calculated sample size is 96. As the annual number of patients newly diagnosed as multiple myeloma isaround 30 in the Department of Pathology, Government Medical College Kottayam, this study intends to include all diagnosed cases of multiple myeloma received during the study period.

\section{Research Hypothesis}

Microvessel density has various expressions in various morphological types of myeloma

\section{Sampling Method}

Continuous sampling methodon bone marrow aspirate and biopsy of patients received in the department of Pathology, Govt. medical college, Kottayam during the study period.

\section{Inclusion Criteria}

1. Patients who are newly diagnosed as multiple myeloma irrespective of age, gender, orgeographical distribution

2. Those cases who are having both bone marrow aspirate and biopsy

\section{Exclusion Criteria}

1. Patients on chemotherapy for multiple myeloma

2. Previously treated cases of multiple myeloma 


\section{Study Tools}

1. Instruments to take bits of tissues to be studied.

2. Reagents for tissue processing.

3. Instruments for making paraffin blocks and cutting thin sections from it.

4. Glass slides and cover slips for mounting.

5. Microscope

6. Eosin- Haematoxylin staining.

7. Antibodies against kappa and lambda and CD 34

8. Clinical proforma

\section{Study Procedure}

Bone marrow aspirate and trephine biopsy of all cases are received at the Dept. of Pathology. The morphological patterns of multiple myeloma are studied on the bone marrow aspirate which is stained using leishman stain. Proliferation and angiogenesis are studied on the bone marrow biopsy using CD 34.

- Bone marrow biopsies are fixed in $10 \%$ formalin and decalcified in $10 \%$ EDTA

- After routine processing 4 micrometre sections are cut and stained with hematoxylin and eosin.

- The sections obtained from patients of myeloma are examined for morphological changes.

\section{Measurement of CD 34 immunostaining}

Angiogenesis parameter studied is the microvessel density done manually on light microscopy. Microvessel density is estimated by counting the number of microvessels in three "hotspots" at 400X magnification. Blood vessels are highlighted by immunostaining endothelial cells with a monoclonal antibody to CD 34

1. The whole section is scanned with a light microscope under a low magnificaton

2. The area with the highest number of microvessels is identified as the hot spot and microvessels are counted under a higher magnification in this area.
3. After determining the microvessel counts of all patients the average microvessel density is calculated. It is regarded as the cut-off value

4. Patients with microvessel counts above this cutoff value are classified as high microvessel density and patients with counts below this value are classified as low microvessel density

\section{Data Management and Analysis}

The data was entered in Microsoft excel and further statistical analysis wasdone using SPSS software (version 25).

\section{Results}

The present study was conducted on bone marrow aspirate and trephine biopsy of 64 patients received in the Department of Pathology, Government Medical College, Kottayam.

The youngest patient in the study group was 42 years of age and oldest patient was 81 years of age. The mean age of the study group was $\mathbf{6 1}$ years. 8 cases belonged to the age group of 40-50 years, 18 cases belonged to the age group of 50-60 years, 28 cases belonged to the age group of 60-70 years and 10 cases were of above 70 years. The study group consisted of 33males $(51.56 \%)$ and 31 females $(48.43 \%)$ with male to female ratio of 1.06:1. Erythrocyte sedimentation rate was elevated in all the cases with 44 of them showing a value of more than $100 \mathrm{~mm} / \mathrm{hr}$. Normocytic normochromic anaemia was the most commonly observed peripheral smear pattern. Of the study group haemoglobin levels were normal in 14 patients and the rest of them were anaemic.47 patients showed exaggerated rouleaux formation in the peripheral smear.

In the bone marrow aspirate erythroid, myeloid and megakaryocytes were relatively suppressed. The morphology and percentage of plasma cells in the bone marrow are well established prognostic factors. $48.44 \%$ of the patients were having a plasma cell percentage of more than $50 \%$ at the time of diagnosis.51.56\% of the patients had plasma cell infiltrate of less than $50 \%$ in the biopsy. 


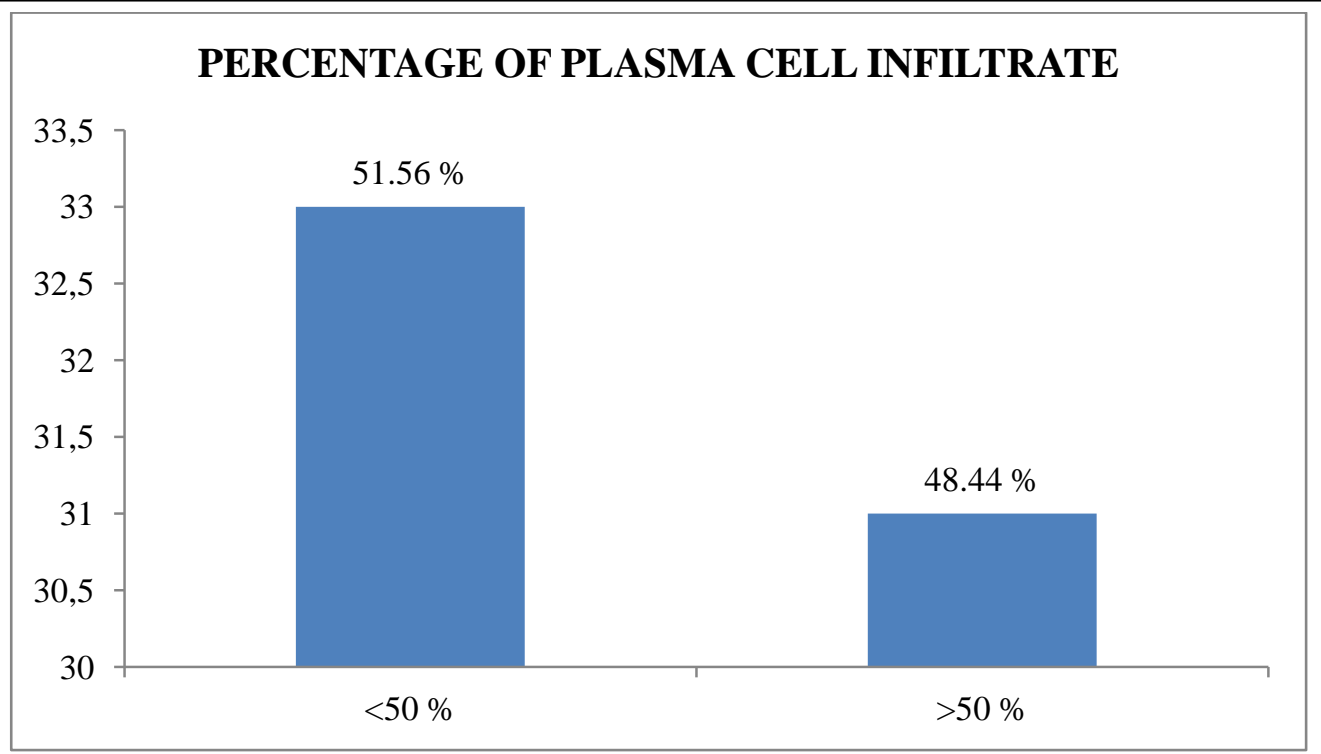

Percentage of plasma cell infiltrate in the aspirate smeares

Plasmacytic morphology was observed in 37 patients .These cell were oval with eccentrically placed nucleus and abundant basophilic cytoplasm. The nuclear chromatin was dense with a perinuclear hof. Plasmablastic morphology was observed in 27 patients which were round with centrally placed large nucleus, round nucleoli and scant rim of cytoplasm.

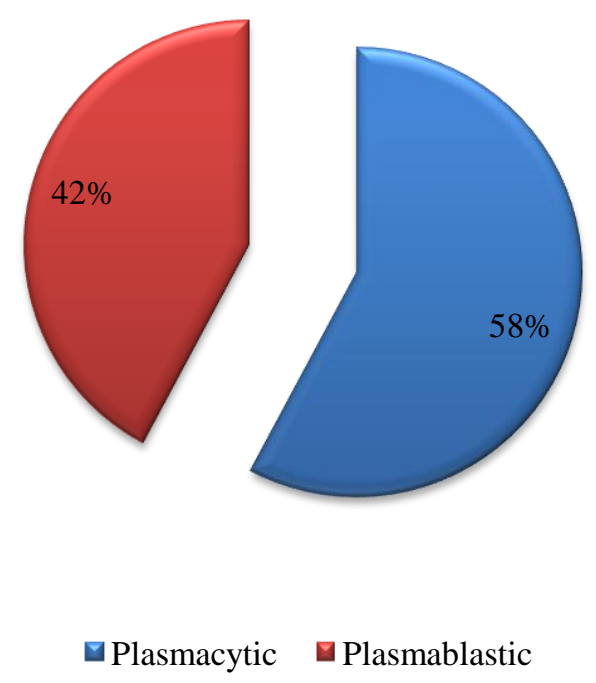

\section{Morphological types of myeloma}

Complete marrow replacement was observed in 43 patients. The plasma cells were dispersed in the marrow in 13 patients and a nodular/focal infiltration in individual marrow spaces was seen in 8 patients. Normal hematopoiesis was suppressed in 62 cases $(96.87 \%)$ whereas it was normal only in 2 cases. In all the 64 cases monoclonality was proved by kappa and lambda light chain restriction. The cut off limit for microvessel density calculated was 18.A microvessel density of more than 18 was seen in 28 patients. 36 patients showed low microvessel density. 


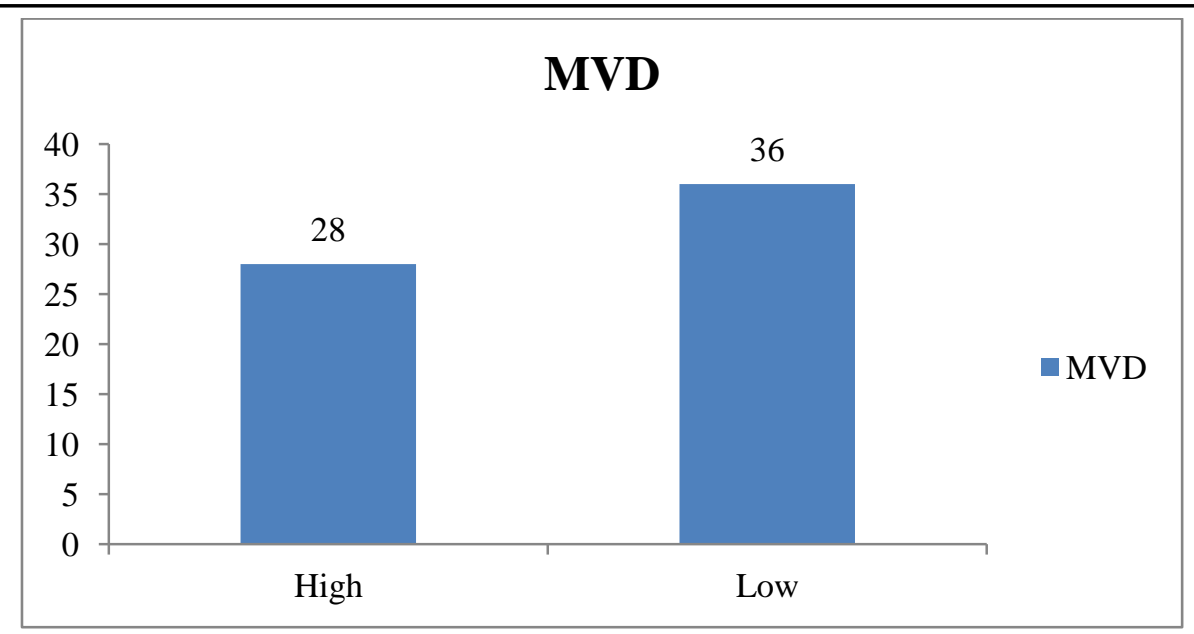

MVD as assessed by CD 34

Comparison of the Plasma Cell Percentage with Plasma Cell Morphology

Plasmacytic morphology was observed in 37 patients and plasmablastic morphology was observed in 27 patients. Plasma cell infiltration of more than $50 \%$ was observed in all cases with plasmablastic morphology.

\begin{tabular}{|l|c|c|c|}
\hline PLASMA CELL \% & PLASMACYTIC & PLASMABLASTIC & TOTAL \\
\hline$<50 \%$ & 33 & 0 & 33 \\
\hline$>50 \%$ & 4 & 27 & 31 \\
\hline TOTAL & 37 & 27 & 64 \\
\hline
\end{tabular}

Relation between Plasma Cell Morphology and Microvessel Density

Microvessel density was found to be high in plasmablastic type.

\begin{tabular}{|l|c|c|c|}
\hline & \multicolumn{3}{|c|}{ MVD } \\
\hline & HIGH & LOW & TOTAL \\
\hline PLASMACYTIC & 3 & 34 & 37 \\
\hline PLASMABLASTIC & 25 & 2 & 27 \\
\hline TOTAL & 28 & 36 & 64 \\
\hline
\end{tabular}

Photomicrographs

Bone Marrow Aspirate

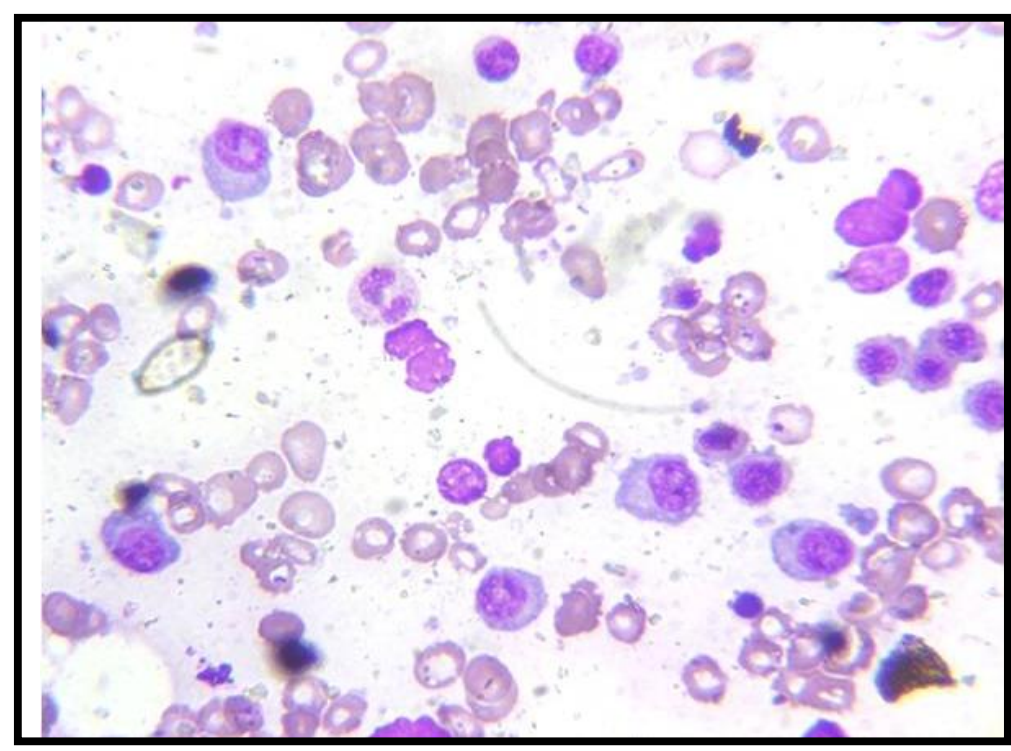

Multiple Myeloma 


\section{JMSCR Vol||08||Issue||02||Page 972-980||February}

Bone Marrow Trephine

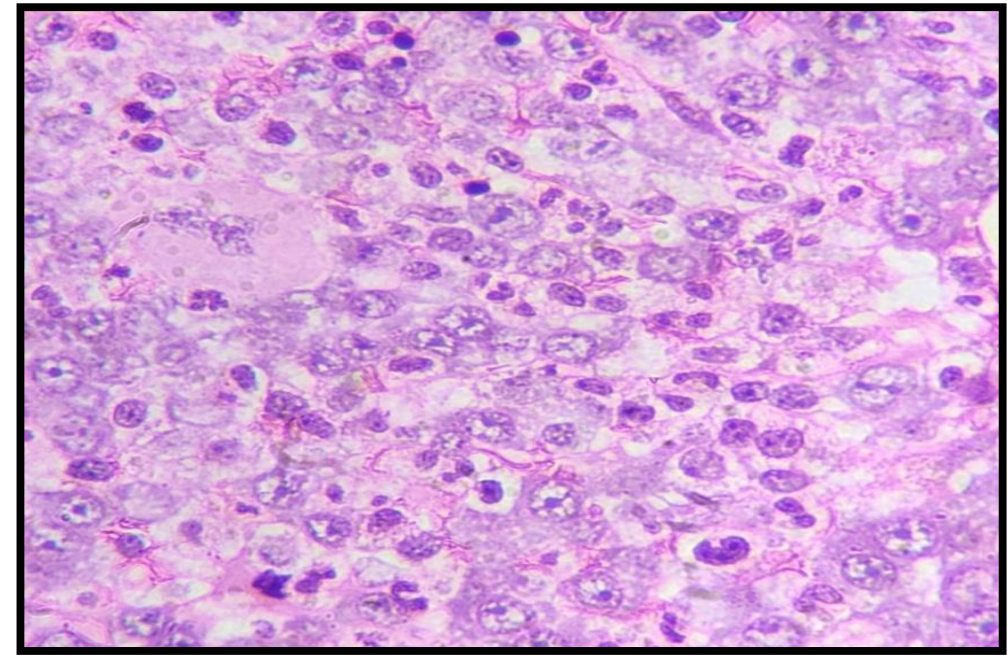

Multiple Myeloma

Monoclonality

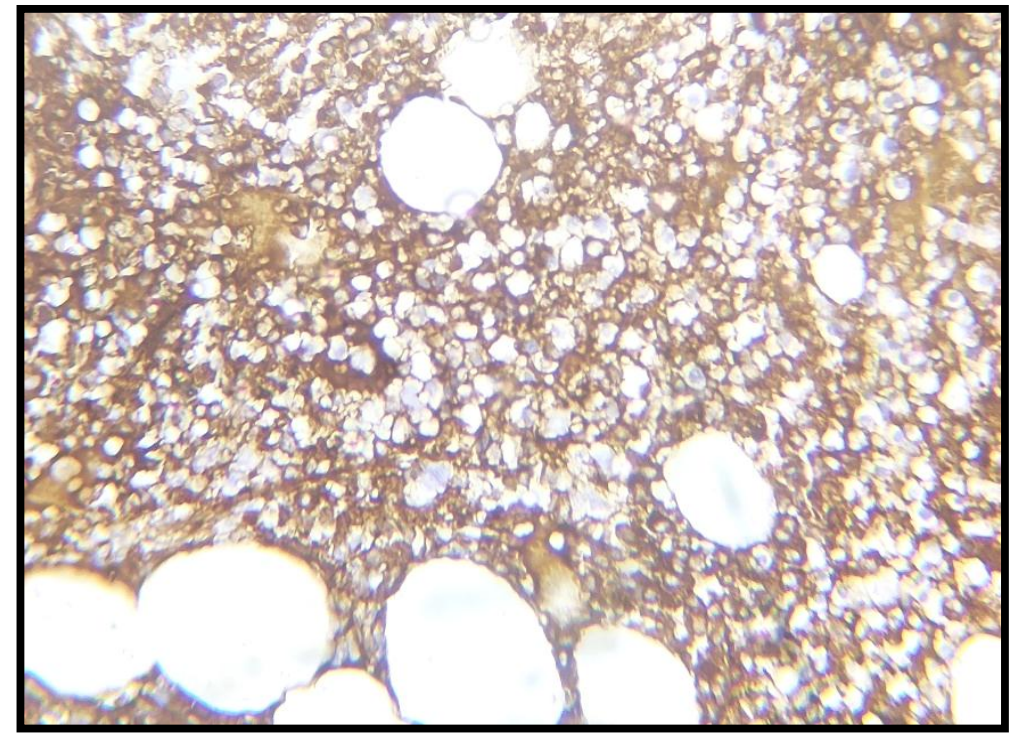

Kappa Positivity

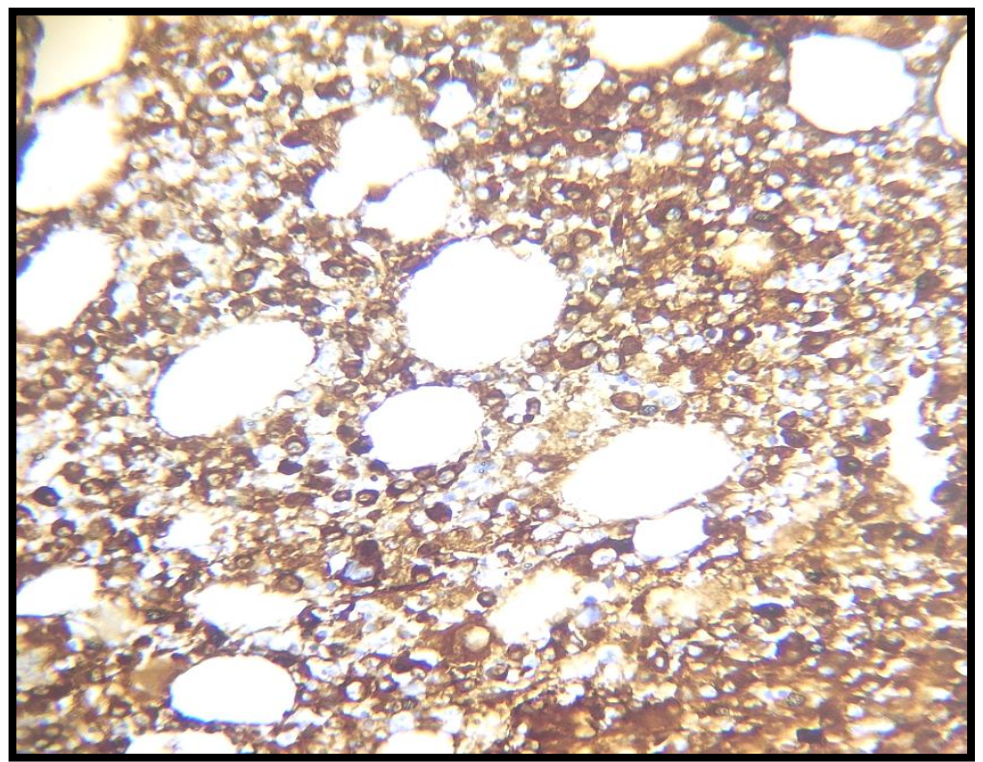

Lambda Positivity 
MVD as assessed by CD 34

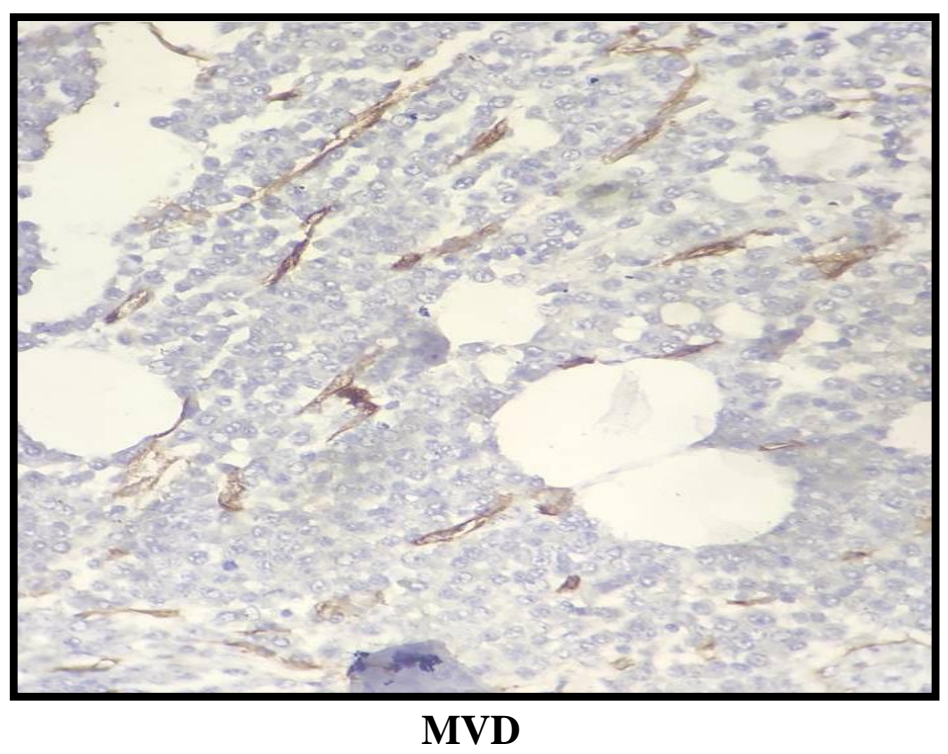

\section{Discussion}

The mean age of the study population in our study was 61 years which is same as that of a study conducted by Nisha $J$ Marla etal ${ }^{86}$ in 2015 in which the mean age was 61 years. Similarly, in a study conducted by $\mathrm{J}$ L Xu et $\mathrm{al}^{(87)}$ in 2002 the mean age was 65 years. The Male: Female ratio in the present study was 1.06:1which was comparable to a study by $\mathrm{J} \mathrm{L} \mathrm{Xu}$ et $\mathrm{al}^{(87)}$ in which the male to female ratio was 1.25 :1.In a study by Anna Carter et $\mathrm{al}^{884)}$, the male to female ratio was1.6: 1.

\section{Association between Micro Vessel Density (MVD) and Plasma Cell morphology}

Micro Vessel Density * Plasma Cell Type Crosstabulation

\begin{tabular}{|c|c|c|c|c|c|}
\hline & & & \multicolumn{2}{|c|}{ Plasma Cell Type } & \multirow[b]{2}{*}{ Total } \\
\hline & & & plasmacytic & plasmablastic & \\
\hline \multirow[t]{4}{*}{ Micro Vessel Density } & high & Count & 3 & 25 & 28 \\
\hline & & $\begin{array}{l}\% \text { within Plasma Cell } \\
\text { Type }\end{array}$ & $7.9 \%$ & $89.3 \%$ & $42.4 \%$ \\
\hline & Iow & Count & 35 & 3 & 38 \\
\hline & & $\begin{array}{l}\% \text { within Plasma Cell } \\
\text { Type }\end{array}$ & $92.1 \%$ & $10.7 \%$ & $57.6 \%$ \\
\hline \multirow{2}{*}{\multicolumn{2}{|c|}{ Total }} & Count & 38 & 28 & 66 \\
\hline & & $\begin{array}{l}\% \text { within Plasma Cell } \\
\text { Type }\end{array}$ & $100.0 \%$ & $100.0 \%$ & $100.0 \%$ \\
\hline
\end{tabular}

The association between microvessel density and plasma cell morphology was statistically significant with a $\mathrm{p}$ value of 0.00 ..Therefore we conclude that plasmablastic will have a higher
Microvessel density compared to plasmacytic. This is comparable to a study done by $\mathrm{J} \mathrm{L} \mathrm{Xu} \mathrm{et} \mathrm{al}$ in 2002. 
Association between Plasma Cell Percentage and Micro Vessel Density

Micro Vessel Density * Plasma Cell Percentage Crosstabulation

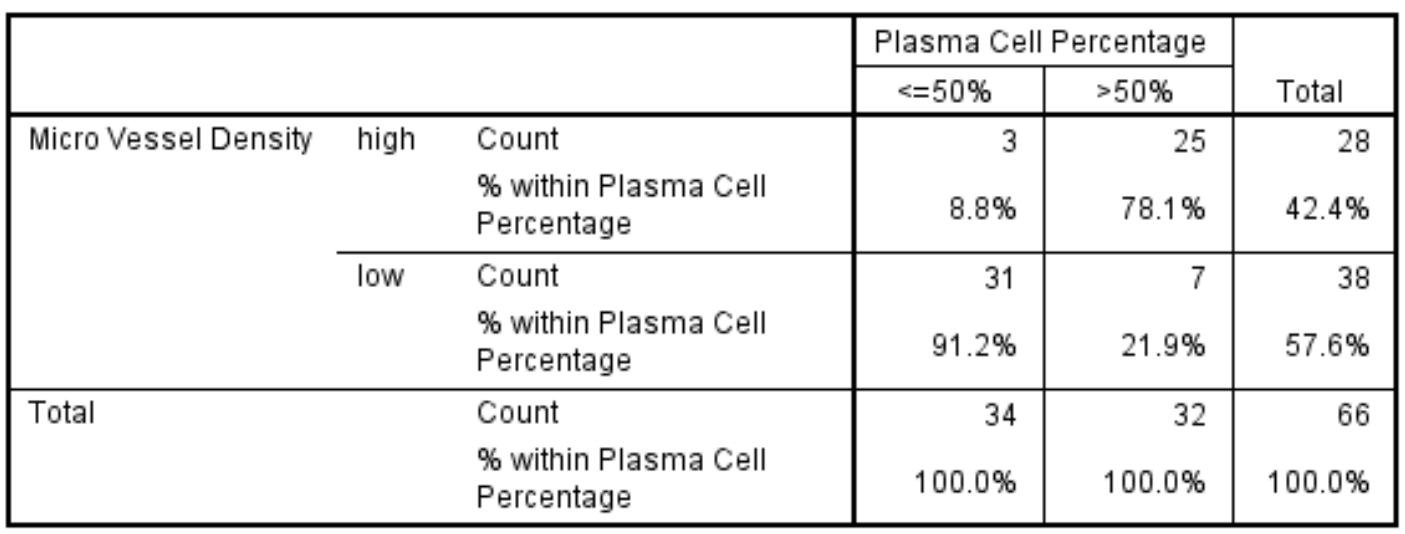

From the cross validation table, we can see that plasma cell percentage $>50 \%$ is more likely to have a high micro vessel density which was statistically significant with a $p$ value of 0.00 . we conclude that having plasma cell percentage of
$>50$ is more likely to have a high microvessel density. This is comparable to a study done by $\mathrm{J} \mathrm{L}$ $\mathrm{Xu}$ et al in 2002 and M G Alexandrakis et al ${ }^{89}$ in 2003.

\section{Association between Micro Vessel Density and Plasma Cell Distribution}

Micro Vessel Density * Plasma Cell Distribution Crosstabulation

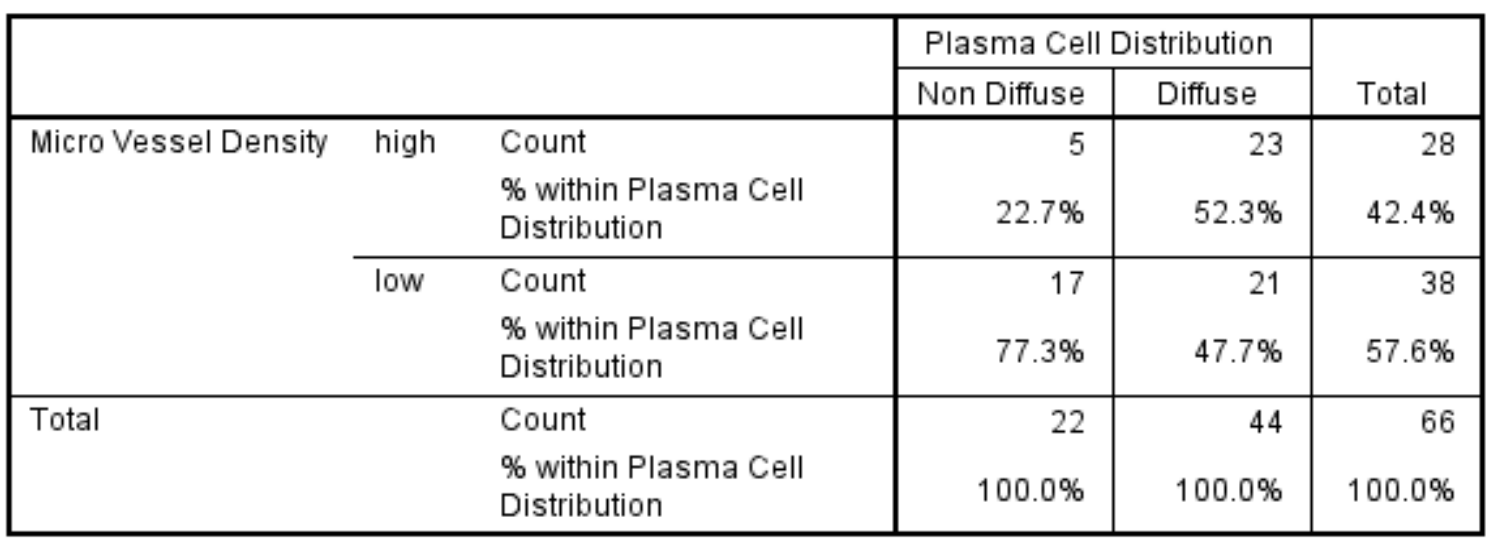

Cross validation table indicates Diffuse cell type to have a high micro vessel density with a significant $p$ value of 0.022 .

\section{Conclusion}

The present study was conducted:

1. To describe the various morphological types of myeloma in bone marrow examination and its kappa and lambda expression

2. To assess the microvessel density using CD 34 in the bone marrow biopsy of patients with multiple myeloma
The conclusions are:

- In our study, myeloma with plasma cell morphology constituted $57.82 \%$ and plasmablastic morphology constituted $42.18 \%$.

- A high microvessel density above the cut off value was seen in 28 cases $(43.75 \%)$ and a low MVD in 36 cases $(56.25 \%)$.

- In all the cases monoclonality was proved by kappa and lambda light chain restriction.

- In the present study, plasmablastic morphology was found to have a higher 
microvessel density compared to plasmacytic type.

- Our data suggested that a higher microvessel density was seen in cases with plasma cell percentage of more than $50 \%$ and diffuse plasma cell infiltration in the bone marrow.

\section{Acknowledgment}

I express my sincere gratitude to Dr Sankar S,Professor and Head of Department of Pathology, my guide Dr.Sheeja S and my coguide Dr Renu Thampi for the valuable guidance, motivation and help during this study and throughout my course.

\section{References}

1. Chawla. N, Kataria. S.P, S. Malik, N.Sharma and S. Kumar; Histopathological Spectrum of Central Nervous System Tumours in a tertiary care referral centre- A one year study. International Journal of Basic and Applied Medical Sciences. 2014;4(2):141-145.

2. Nibhoria $S$, KaurTiwana $K$, Phutela $R$, Bajaj A, Chhabra S. Histopathological Spectrum of Central Nervous System Tmours: A single centre study of 100 cases. International Journal of Scientific Study, 2015;p 130- 134. 2015;3(6):130134.

3. Louis D. WHO classification of tumours of the central nervous system. Lyon: International Agency for Research on Cancer; 2016.

4. Dalia. A. Elsers and Noha. A. Aboulhagag; Expression of Ki-67, EGFR and its ligand in different grades of Meningiomas; AAMJ, 2012; p 34-56.

5. Scholzen T, Gerdes J. The Ki-67 protein: From the known and the unknown. Journal of Cellular Physiology. 2000;182(3):311322
6. Drake R, Vogl W, Mitchell A, Gray H. Gray's anatomy for students. Philadelphia, PA: Churchill Livingstone/Elsevier; 2010.

7. Young B, O'Dowd G, Woodford P. Wheaters functional histology. 6th ed. Philadelphia: Reed Elsevier; 2014: 384401

8. Sengupta S, Banerjee U, Chatterjee S, Chatterjee U, Ghosh S, Ghosh A. A study of histopathological spectrum and expression of $\mathrm{Ki}-67, \mathrm{TP53}$ in primary brain tumors of pediatric age group. Indian Journal of Medical and Paediatric Oncology. 2012;33(1):25.

9. Aryal G. Histopathological pattern of central nervous system tumor: A three year retrospective study. Journal of Pathology of Nepal. 2011;1(1):22-25.

10. Alomar S. Clinical manifestation of central nervous system tumor. Seminars in Diagnostic Pathology. 2010;27(2):97-104.

11. Harnsberger $H$, Dillon $W$. Imaging Tumors of the Central Nervous System and Extracranial Head and Neck. CA: A Cancer Journal for Clinicians. 1987;37(4):225-238.

12. Essig M, Anzalone N, Combs S, Dörfler A, Lee S, Picozzi P et al. MR Imaging of Neoplastic Central Nervous System Lesions: Review and Recommendations for Current Practice. American Journal of Neuroradiology. 2011;33(5):803-817. 